\title{
論文
}

\author{
접힌 자국이 있는 멤브레인의 주름 거동 해석 \\ 우경식*
}

\section{Analysis of Wrinkling for Creased Thin Membrane}

Kyeongsik Woo*

\begin{abstract}
In this paper, the wrinkling behavior of vertically creased corner-loaded square membranes was studied using geometrically nonlinear post-buckling analysis. The membranes were modeled using shell elements, and the meshes were seeded with semi-random geometrical imperfection to instigate the buckling deformation. A pristine and creased membranes with various initial deployment angles were considered in the analyses and the results were compared. Results showed that local wrinkles initiated near the corner where the higher load was applied, which grew to form a single diagonal global wrinkle as the load ratio increased. It was also found that the local wrinkle initiation and the global wrinkle formation were significantly dependent on the initial deployment angles.

\section{초 록}

본 논문에서는 수직방향으로 접은 사각형 멤브레인의 주름 거동을 기하학적 비선형 후 좌굴 해석을 사용하여 연구하였다. 멤브레인은 쉘 요소로 모델링 하였고 하중은 멤브레인 의 코너에서 대각선 방향으로 가하였다. 해석에는 다양한 각도의 초기 전개각을 가지는 멤브레인을 고려하였고 접힌 자국이 없는 경우에 대해서도 해석을 수행하여 그 결과를 비 교하였다. 해석결과 주름은 큰 코너하중이 가해진 지역에서 국부적으로 발생하였는데, 이 국부 주름은 하중 비의 증가에 따라 점차 성장하여 전역 주름으로 발전하였다. 또한 주름 의 발생 및 성장 거동은 접힌 자국의 초기 전개각에 좌우되는 경향을 보였다.
\end{abstract}

Key Words : Membrane(멤브레인), Crease(접힌 자국), Wrinkle(주름), Initial deplolyment angle(초기 전개각), Post-buckling analysis(후좌굴 해석)

\section{I. 서 론}

최근 초경량 및 초대형 Gossamer 우주구조물 의 개발이 본격화 되고 있다. 초경량 우주구조물 들은 주로 얇은 멤브레인과 팽창 전개식 구조 요 소로 구성되는데, 이들은 무게가 가벼울 뿐만 아 니라 발사체에 탑재하여 우주로 보내기 쉽도록 아주 작은 부피로 패키징 할 수 있는 것이 특징

十2008년 6월 10일 접수 2008년 7월 31일 심사완료

* 정회원, 충북대학교 토목공학부

교신저자, E-mail: kw3235@cbnu.ac.kr

충북 청주시 흥덕구 개신동 12
이다[1-2]. 멤브레인을 주 구조로 하는 Gossamer 우주구조물의 대표적인 예로는 대형 우주망원경 의 멤브레인 거울[3], 안테나[4], 솔라세일[5] 등이 있다.

그러나 두께가 얇은 멤브레인은 굽힘강성이 거의 없으므로 압축응력이 가해지면 즉시 좌굴이 발생하는데 이를 주름(wrinkle)이라고 한다. 또한 멤브레인 구조를 우주로 보내기 위해 패키징 할 때에는 일정한 패턴으로 접게 되는데 이 과정에 서 접힌 자국(systematic crease)이 발생하게 된다 [6-7]. 패키징 외에도 제작이나 운송 등의 과정에 서도 크고 작은 접힌 자국이 발생하는데 이들은 
전자가 일정한 패턴을 가지는 것에 비해 임의의 형상 및 분포(random crease)를 가진다[8].

멤브레인에 주름이 발생하면 하중의 지지능력 과 전달경로가 크게 변화하게 된다. 또한 접힌 자국은 주름의 거동에 큰 영향을 미치는 것으로 알려져 있을 뿐만 아니라 패키징된 멤브레인 구 조물이 우주공간에서 어떻게 전개되는지에 대한 관심이 지대하므로 현재 접힌 멤브레인의 전개거 동에 대한 연구가 활발히 진행되고 있다[9].

멤브레인의 주름거동에 대한 연구는 그동안 많은 연구자들에 의하여 활발히 진행되어 왔다. 그러나 이에 비하여 접힌 자국이 주름거동에 미 치는 영향에 대해서는 아직 연구가 미미한 상태 이며 일부 연구가 단편적으로 수행된 정도이다. Papa 와 Pellegrino[10]는 일정한 패턴으로 접힌 사각형 멤브레인의 주름 거동을 셀요소에 의한 후좌굴 해석을 수행하여 연구하였고, Gough 등 [11]과 Hossain 등[12]은 횡방향의 접힌 자국이 있는 사각형 멤브레인에 대해 멤브레인 요소를 사용하여 해석을 수행하였다. 이들은 각각 유한 요소법에 의한 멤브레인 주름해석의 대표적인 두 가지 접근방법인 쉘 요소법과 멤브레인 요소법을 사용하고 있는데, 접힌 자국이 있는 멤브레인의 전개시 발생하는 주름거동해석을 시도한 정도로 접힌 자국이 주름에 미치는 영향에 대해서 상세 히 분석하지는 못하였다.

본 논문에서는 사각형 멤브레인 형상에 대해 접힌 자국과 주름거동의 상호작용에 대해서 쉘 요소에 의한 후좌굴 해석을 통해 연구하였다. 해 석과정에서 먼저 접혀진 사각형 멤브레인에 대해 어느 정도 타당한 기준전개형상을 얻기 위하여 코너에서 동일한 크기의 하중을 가하였다. 다음 으로 코너하중을 불균일하게 하여 코너에서 국부 적으로 주름을 발생시키도록 하였으며, 주름이 발생한 후에는 하중비를 계속적으로 증가시키면 서 주름의 성장을 관찰하였다. 그리고 다양한 초 기 전개각을 가지는 멤브레인을 고려하여 접힌 자국의 정도가 주름의 성장에 어떤 영향을 미치 는지 체계적으로 조사하였다.

\section{ㅍ. 해 석}

Fig. 1은 코너에서 인장하중을 받고 있는 $500 \times 500 \mathrm{~mm}^{2}$ 크기의 사각형 Kapton 멤브레인 형상을 보이고 있다. 멤브레인의 두께는 $25 \mu \mathrm{m}$ 이며, 그림에서 중앙 부분의 점선은 접힌 자국을 나타낸다. 하중을 가하기 위하여 멤브레인의 코 너부분은 대각선에 수직하게 $14.14 \mathrm{~mm}$ 의 길이로
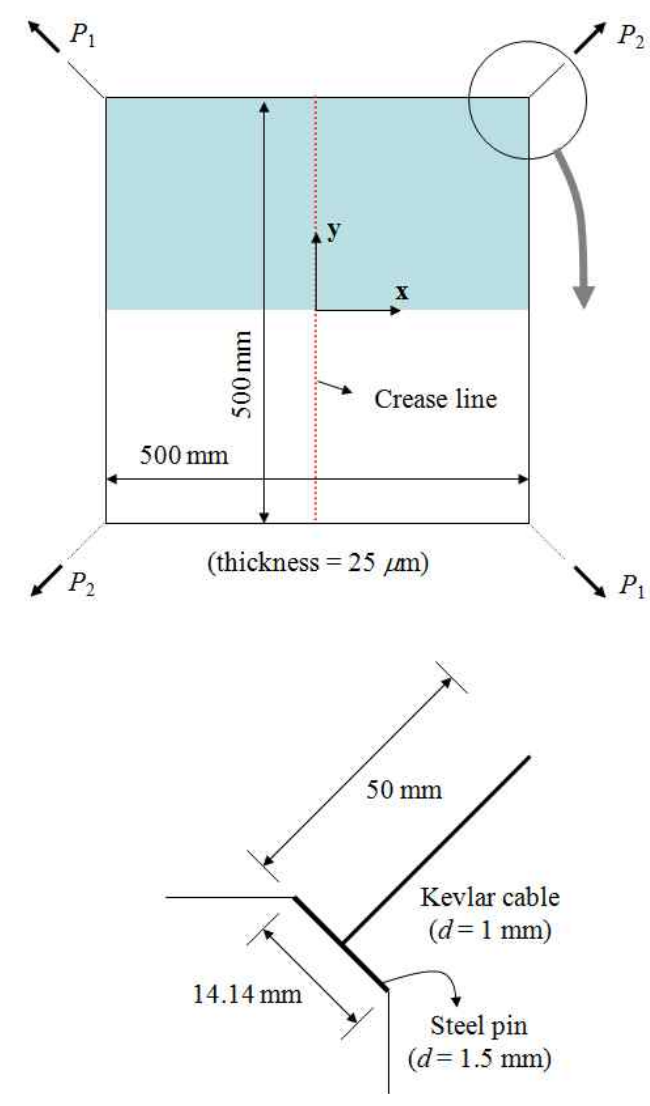

Fig. 1. Corner loaded creased square membrane configuration

자른 후 지름 $1.5 \mathrm{~mm}$ 의 강철 핀을 부착하였고, 그 중앙에 다시 길이가 $50 \mathrm{~mm}$ 이고 지름 $1 \mathrm{~mm}$ 인 케블라 선을 연결하였다.

해석에 사용된 멤브레인의 물성치는 $E=2.5$ $\mathrm{GPa}, v=0.34$ 이고[13], 강철 핀 및 케블라 선의 탄성계수는 각각 $210 \mathrm{GPa}$ 와 $140 \mathrm{GPa}$ 이다.

본 연구에서 해석은 상용 유한요소 프로그램인 ABAQUS를 사용하여 수행되었다. 멤브레인은 얇 은 쉘 요소(S4R5/S3R)로, 강철핀은 보 요소(B31) 로, 그리고 케블라 선은 막대 요소(T3D2)로 모델 링 하였다. 좌굴변형을 유발하기 위하여 메쉬 내 부에 위치한 절점들에 대해 면외 방향으로 멤브 레인 두께의 $1 \%$ 이내의 크기를 가지는 미소의 무작위성 기하학적 결함(random imperfection)을 가하였다. 또한 좌굴발생 이후의 계산과정을 안 정화시키기 위하여 $*$ STATIC, STABILIZE 옵션을 사용하였다[10].

일반적으로 멤브레인의 주름 거동 연구에서 쉘 요소에 의한 후좌굴 해석 방법은 주름의 형상 
Table 1. Element types and no. of elements

\begin{tabular}{|c|c|c|c|}
\hline $\begin{array}{c}\text { Element } \\
\text { Type }\end{array}$ & S4R5/S3R & B31 & T3D2 \\
\hline NEL & 79,952 & 8 & 2 \\
\hline
\end{tabular}

을 명백하게 보여주는 장점이 있으나, 수렴된 결 과를 얻기 위해서, 그리고 미세한 주름패턴을 상 세히 보여주기 위해서는 매우 많은 수의 요소를 사용하여야 한다. 본 연구에서는 메쉬 수렴연구 를 수행하여 요소수를 결정 하였다. 해석에 사용 된 요소의 종류와 수는 표 1 에 정리하였다.

Fig. 1에서 보는 바와 같이 코너하중을 받고 있는 사각형 멤브레인 형상은 주기적 대칭성 (cyclic symmetry)을 가진다. 본 연구에서는 주기 대칭성을 이용하여 그림에서 진한 색으로 표시된 윗부분에 대해서만 모델링을 수행하였다. 유한요 소 메쉬에 대해 멤브레인의 중앙 지점에서는 면 내 변위 $(u, v)$ 와 모든 회전 자유도 $\left(\phi_{x}, \phi_{y}, \phi_{z}\right)$ 를 구 속하고, 케블라 선의 끝에서는 면외 방향의 변위 자유도 $(W)$ 만을 구속하도록 경계조건을 가하였다. 주기적 대칭성은 멤브레인의 중앙의 $y=0$ 인 수평선을 따라서 다음과 같은 다중점 구속조건 (multi-point constraint)으로 구현하였다.

$$
\begin{aligned}
& u(x, 0, z)=-u(-x, 0, z) \\
& v(x, 0, z)=-v(-x, 0, z) \\
& w(x, 0, z)=w(-x, 0, z) \\
& \phi_{x}(x, 0, z)=-\phi_{x}(-x, 0, z) \\
& \phi_{y}(x, 0, z)=-\phi_{y}(-x, 0, z) \\
& \phi_{z}(x, 0, z)=\phi_{z}(-x, 0, z)
\end{aligned}
$$

대각선 방향으로의 인장하중 $P_{1}, P_{2}$ 는 케블라 선의 끝에 가하였다. Fig. 2는 단계별로 가한 하 중스텝을 설명하고 있다. 제 1 단계에서는 모든 방향으로 동일한 하중을 가하여 (즉, $P_{1}=P_{2}$ ) 접 힌 멤브레인을 어느 정도 펼친다. 제 2단계에서 는 좌상귀의 하중 $P_{l}$ 은 제 1 단계에서 가한 값으 로 고정한 채 우상귀의 하중 $P_{2}$ 를 계속적으로 증 가시킨다. 여기서, 제 1 단계에서 멤브레인의 전 개형상을 얻기 위해 가해진 대칭하중 값을 기준 하중 $\left(P_{0}\right.$, baseline load)으로, 그리고 제 2 단계에 서 대각선 방향으로 가해진 인장 하중의 비율 $\left(P_{2} / P_{1}\right)$ 을 하중비(load ratio)로 정의하였다. 본 연구에서 기준하중의 값은 $1 \mathrm{~N}$ 으로, 그리고 최 대 하중비는 4 로 하여 해석을 수행하였다.

Fig. 2 에서 $\psi$ 는 멤브레인의 접힌 자국의 끝 모 서리와 하중평면 사이의 거리로 접힌 자국의 깊 이를 나타낸다. 또한 $\theta_{0}$ 와 $n_{0}$ 는 각각 초기 전개 각(initial deployment angle)과 접힘각(crease angle)을 의미하고 있는데, 이들은 멤브레인의 접

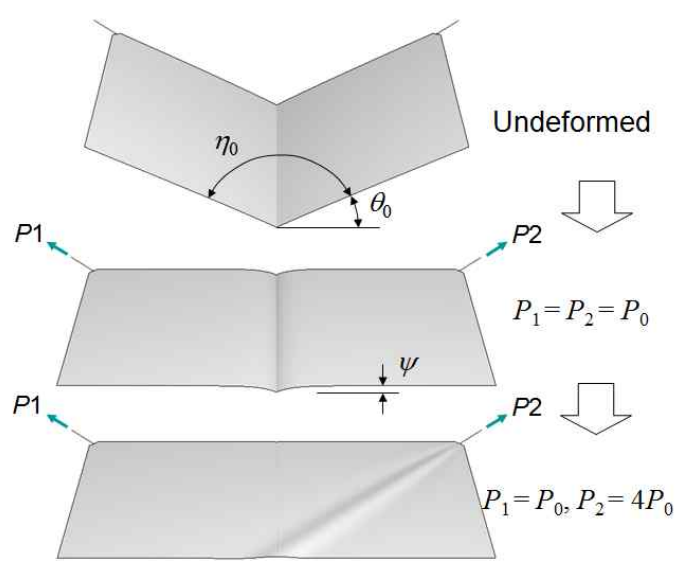

Fig. 2. Schematic of loading steps

힘 세기(crease intensity)를 정의하는 매개변수이 다[14]. 작은 초기 전개각은 멤브레인이 약하게 접혀진 것을, 그리고 큰 초기 전개각은 세게 접 혀진 것을 의미한다. 본 연구에서는 접힘 세기가 주름의 발생 및 성장거동에 미치는 영향을 조사 하기 위하여 다양한 초기 전개각을 고려하였다.

\section{III. 계산결과 및 검토}

본 절에서는 다양한 초기 전개각을 가지도록 접혀진 접힌 멤브레인에서 하중비의 증가에 따라 주름 발생 및 성장거동을 분석하였다.

Fig. 3은 국부주름이 발생하여 성장하기 시작 하는 하중 단계에서 $L_{1}$ 선을 따라 변형된 접힌

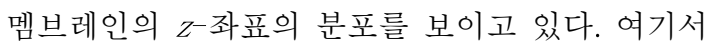
$L_{1}$-선은 Fig. 4 에 보인 바와 같이 멤브레인의 우 상부에서 $P_{2}$ 하중의 방향에 수직하도록 정의되었 다. Fig. 3에서 국부주름의 발생시점은 초기 전개 각에 크게 좌우됨을 알 수 있다. 초기 전개각 $\left(\theta_{0}\right)$ 이 $6.39^{\circ}$ 일 때 주름은 하중비가 약 2.25일 때 발 생하였다. 그러나 초기 전개각이 $16.18^{\circ}$ 일 때에는 이보다 약간 작은 하중비에서 발생하기 시작하 며, 초기 전개각이 $37.33^{\circ}$ 일 때에는 이 시점에서 이미 국부주름이 잘 발달되어 성장하기 시작하고 있음을 볼 수 있다. 이는 접힌 자국에 의해 유발 된 비등방성 효과에 기인하는 것으로 생각된다 [12]. 수직방향으로 접힌 자국이 있는 멤브레인에 서 수직방향의 탄성계수는 원래의 멤브레인의 탄 성계수와 동일하지만 수평방향의 경우에는 접힌 자국에 의해 크게 낮아지게 되는데, 이것이 마치 하중비를 증가시킨 효과를 주는 것으로 보인다. 또한 접힌 자국에 의해 유발된 비등방성에 의해 
주름의 형상도 비대칭적으로 발생하게 되는데, 이는 초기 전개각이 클 때 더 두드러지게 나타나 게 된다. 그림에서 초기 전개각이 $37.33^{\circ}$ 일 때 우측 주름의 크기가 좌측의 그것 보다 더 크게 형성됨을 확연히 관찰할 수 있다. 그러나 초기 전개각이 감소함에 따라 비등방성 효과는 점차 감소하였고, $6.39^{\circ}$ 일 때에는 거의 미미하여 주름 형상이 거의 대칭으로 나타났다.

주름의 발생 및 성장과정은 부응력(minor principal stress)의 분포를 통해서 좀 더 명확히 이해할 수 있다. Fig. 5는 국부주름 발생 단계의 하중비인 $P_{2} / P_{1}=2.0 \sim 2.3$ 에서 부응력의 분포 를 보이고 있다. 그림의 우상귀에서 부채살처럼 보이는 것이 발생한 주름을 형상을 나타낸다. 부 응력은 멤브레인의 윗면(SPOS)에 대해 도시되었 으므로 양의 응력값을 가지는 지역은 주름의 위 로 볼록한 부분을, 그리고 음의 값을 가지는 지 역은 아래로 볼록한 부분을 의미한다. 이 그림에 서도 국부주름은 앞에서 설명한 바와 같이 큰 초 기 전개각을 가지는 멤브레인에서 먼저 발생하고 있음을 볼 수 있다. 초기 전개각이 $16.18^{\circ}$ 인 경우 국부주름은 하중비가 2.1일 때 우상귀의 $P_{2}$ 코너 에서 막 발생하기 시작하고 있으나 $37.33^{\circ}$ 인 경 우에는 이미 잘 발달되어 있음을 보이고 있다. 반면에 초기 전개각이 $6.39^{\circ}$ 일 때에는 하중비가 2.3에 이르러서 겨우 나타나기 시작하였다. 하중 비의 증가에 따라 모든 경우에서 주름은 점차 성 장하게 되는데 현재까지의 하중 단계에서는 초기 전개각이 큰 경우가 가장 빠른 성장을 보였다.

Fig. 6는 멤브레인의 중앙에서 $x=0$ 인 수직선

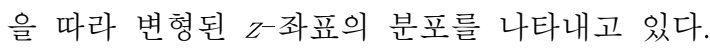
이 선은 Fig. 4 에서 $L_{2}$ 선으로 표시되어 있는데 접힌 자국선과 일치한다. 멤브레인 중앙에서 발 생하는 주름은 전역주름으로, $L_{2}$ 선은 전역주름이 접힌 자국을 통과하는 거동을 알아보기 위하여 정의되었다. 그림에 나타난 바와 같이 하중비 $P_{2} / P_{1}=1$ 의 값에서 수평인 접힌 자국 선은 하 중비가 증가함에 따라서 처음에는 면외 방향으로 굴곡이 없이 그대로 위로 이동하기 시작하는 것 을 볼 수 있다. $y=250 \mathrm{~mm}$ 부위에서 위로 말 려 올라간 것은 자유단에서 접힌 부분이 내부에 서 보다 더 쉽게 열리게 되는 것에 기인한다. 초 기 전개각이 클수록 자국의 깊이가 크므로 하중 비의 증가에 더 많은 양의 상향이동을 보였다. 초기 전개각이 $6.39^{\circ}$ 일 때 $L_{2}$-선은 하중비가 약 2.5 정도에서 굴곡된 모습을 보여 전역주름이 시 작되는 것을 알 수 있는데, 전역주름은 하중비가 2.75에 이르면서 본격적으로 그 크기가 증가하 기 시작하였다.

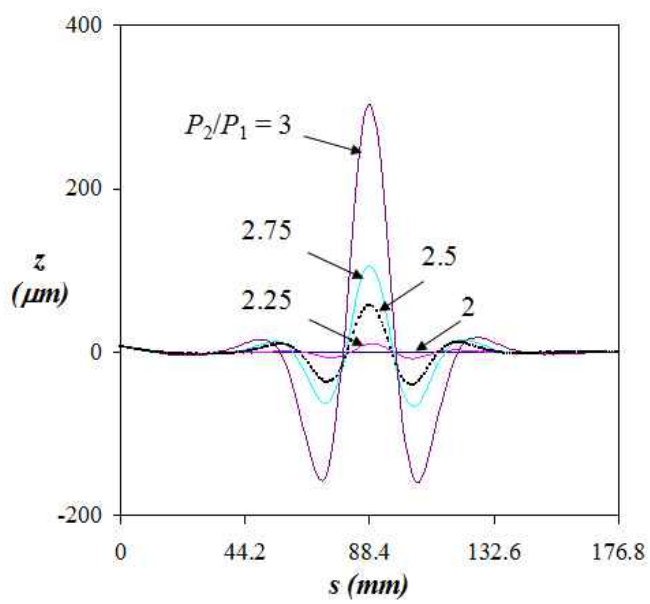

(a) $\theta_{0}=6.39^{\circ}$

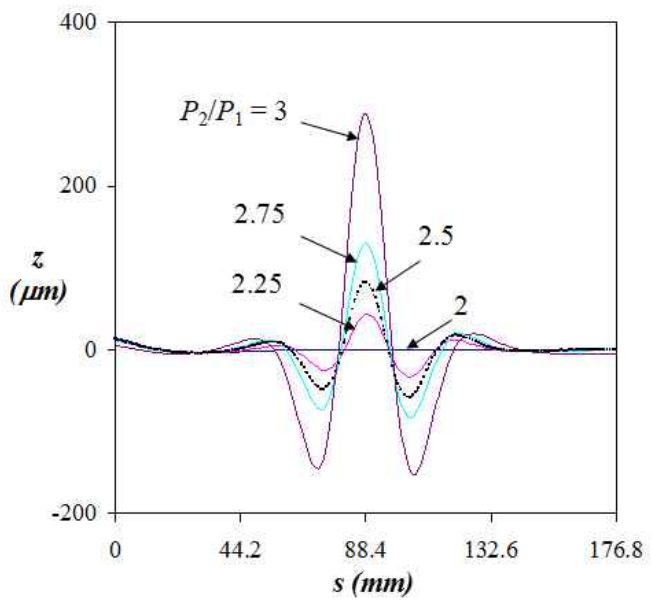

(b) $\theta_{0}=16.18^{\circ}$

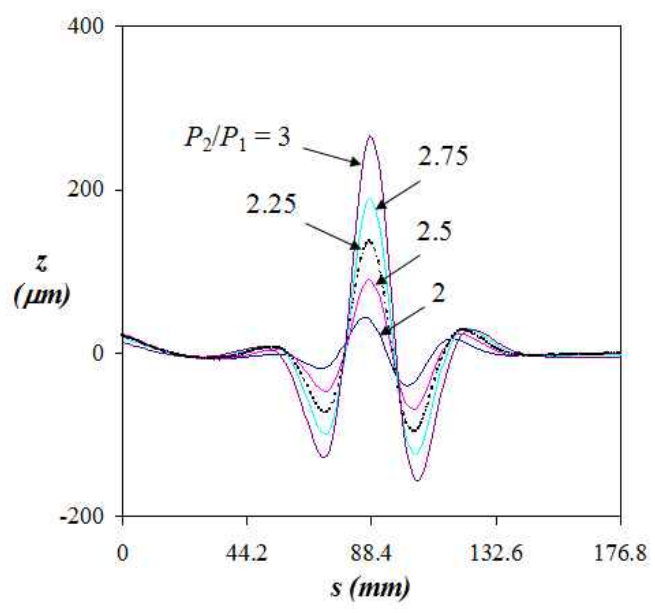

(c) $\theta_{0}=37.33^{\circ}$

Fig. 3. Variation of deformed $z$-coordinates along L1-line 


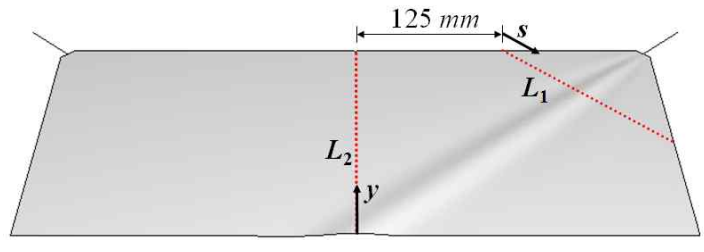

Fig. 4. Definition of L1- and L2-lines

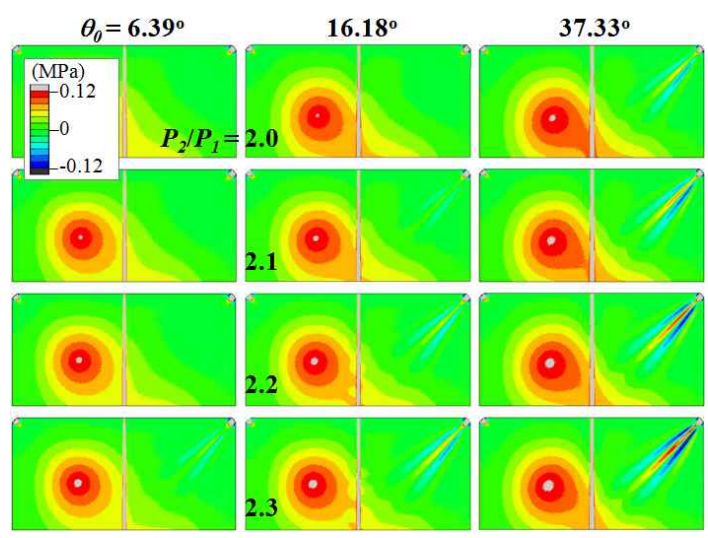

Fig. 5. Distribution of minor principal stresses in the local wrinkle development stage

초기 전개각이 $16.18^{\circ}$ 와 $37.33^{\circ}$ 인 경우 하중비 2.5 에서 더 굴곡된 $L_{2}$ 선 변형을 보여 전역주름도 국부주름의 경우와 마찬가지로 큰 초기 전개각을 가지는 멤브레인에서 먼저 시작하는 것처럼 보인 다. 그러나 하중비를 계속적으로 증가시키면 초 기 전개각이 작을 때 전역주름이 더 빨리 성장하 여 전역주름의 성장속도가 역전되는 것을 알 수 있다. 하중비 $P_{2} / P_{1}=3$ 에서 초기 전개각이 $6.39^{\circ}$ 일 때가 이보다 더 큰 초기 전개각을 가진 경우 에 비하여 전역주름의 크기가 더 크게 나타났다. 이것은 면외 방향으로 튀어나온 접힌 자국이 굽 힘 강성을 보강하는 일종의 스티프너의 역할을 하기 때문으로, 초기 전개각이 클수록 접힌 자국 의 깊이가 깊어 주름이 접힌 자국 선을 통과하려 고 할 때 효과적으로 저항하는 것으로 생각된다.

Fig. 7은 하중비가 $P_{2} / P_{1}=2.9 \sim 3.2$ 의 범위에 서 부응력의 분포를 보이고 있다. 하중비가 2.9 일 때 멤브레인의 우상귀에서의 주름형상은 초기 전 개각이 $37.33^{\circ}$ 일 때 가장 잘 발달되어 있음을 볼 수 있다. 그러나 이보다 큰 하중비에서 주름의 발달은 완전히 역전되는 경향을 보였다. 초기 전 개각이 $6.39^{\circ}$ 일 때 접힌자국의 깊이는 상대적으 로 깊지 않으므로 우상귀의 주름은 잘 성장하여 중앙의 접힌 자국 지역을 거의 저항이 없이 부드

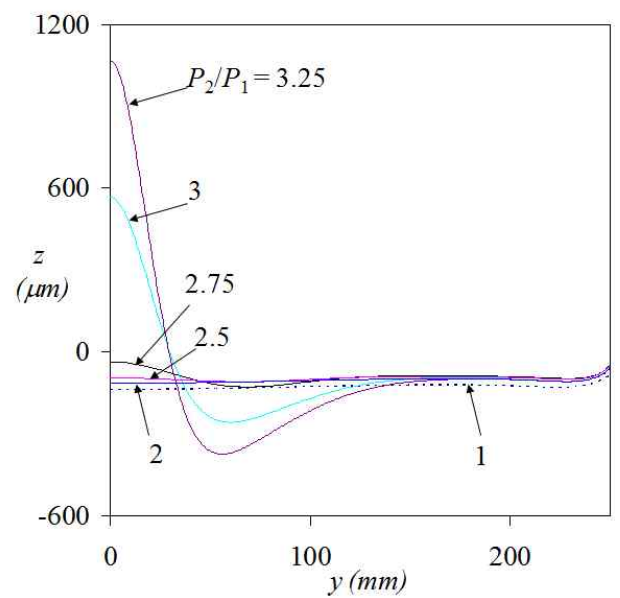

(a) $\theta_{0}=6.39^{\circ}$

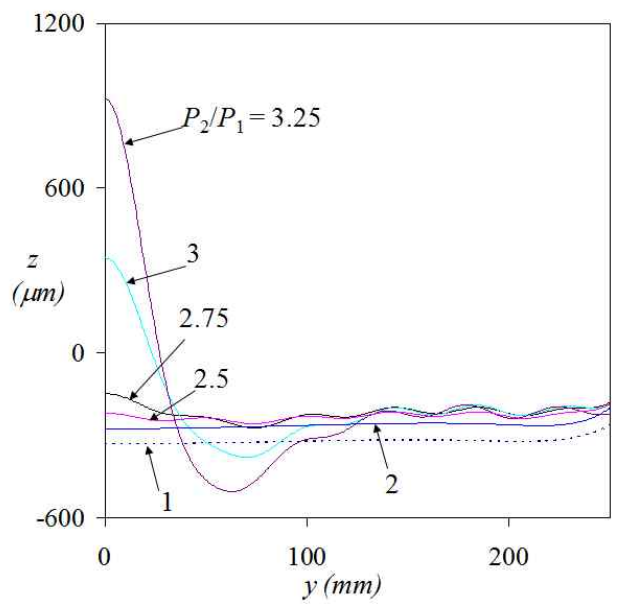

(b) $\theta_{0}=16.18^{\circ}$

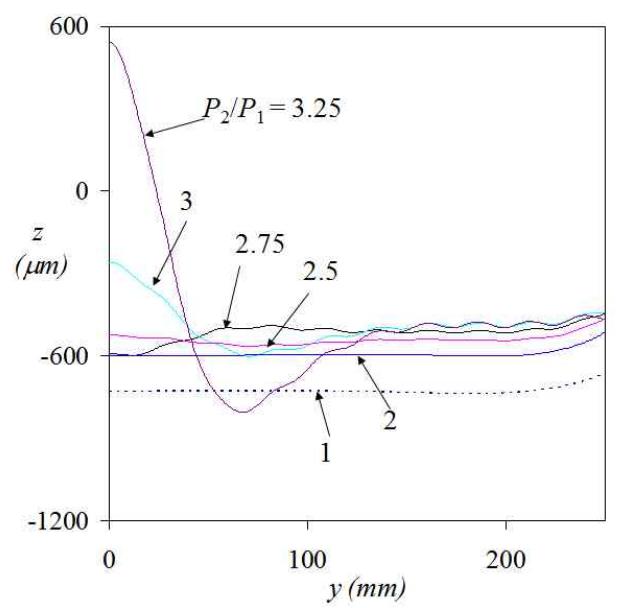

(c) $\theta_{0}=37.33^{\circ}$

Fig. 6. Variation of deformed $z$-coordinates along L2-line 


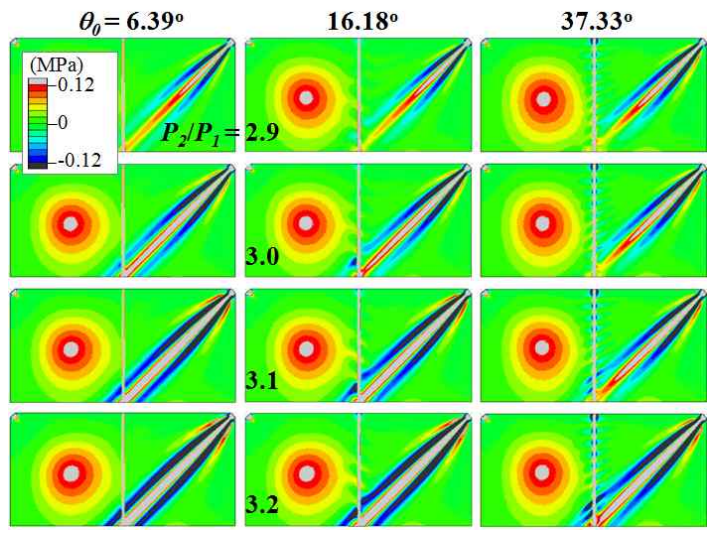

Fig. 7. Distribution of minor principal stresses in the global wrinkle development stage

럽게 통과하였다. 반면에 초기 전개각이 $37.33^{\circ}$ 인 경우에는 국부주름의 성장은 가장 빠르게 성장하 였으나 중앙의 접힌 자국 지역에 도달하면서 접 힌 자국의 저항을 받아 성장속도는 점차 둔화되 었다. 그림에서 하중비가 3.1 일 때 초기 전개각이 $6.39^{\circ}$ 와 $16.18^{\circ}$ 에서 주름은 접힌자국을 완전히 통 과하여 전역주름을 형성하였으나 $37.33^{\circ}$ 인 경우 에는 하중비가 3.2 에서도 아직 완전하게 이루어 지지 않고 있음을 볼 수 있다.

하중비가 증가하여 전역주름이 잘 발달된 이 후에는 멤브레인의 접힌 자국의 정도, 즉 초기 전개각의 크기가 주름의 거동에 미치는 영향은 크게 감소하는 것으로 나타났다. Fig. 8은 하중비 가 4 일 때 $L_{1^{-}}$및 $L_{2}$ 선을 따라 변형된 $Z^{-}$좌표의 분포를 보이고 있다. 여기서 pristine으로 표시된 것은 접힌 자국이 없는 멤브레인에 대한 결과이 다. Fig. 8(a)에서 $L_{1}$ 선을 따라서 주름은 거의 대 칭의 형상을 보이고 있으며 접힌 자국이 없는 경 우와 서로 다른 초기 전개각을 가지도록 접힌 경 우가 큰 차이가 없음을 알 수 있다. Fig. 8(b)의 $L_{2}$ 선을 따르는 분포에서도 주름이 발생하지 않 은 지역 $(50 \mathrm{~mm} \leq y \leq 250 \mathrm{~mm})$ 에서는 초기 전개 각에 따라 접힌 자국이 깊이가 서로 다르므로 명 확한 차이를 보이고 있으나 전역주름이 발생한 지역 $(y \leq 50 \mathrm{~mm})$ 에서는 그 차이가 크지 않았다.

Fig. 9는 하중이 가해진 케블라 선 끝에서 하 중비의 증가에 따른 대각선 방향으로의 변위의 변화를 보이고 있다. Fig. 9(a)에서 $P_{2}$ 방향의 변 위인 $d_{2}$ 는 하중비가 증가함에 따라 계속 증가하 고 있음을 볼 수 있다. 여기서 곡선의 기울기가 변화하는 곳이 전역주름이 발생하는 시점과 일치

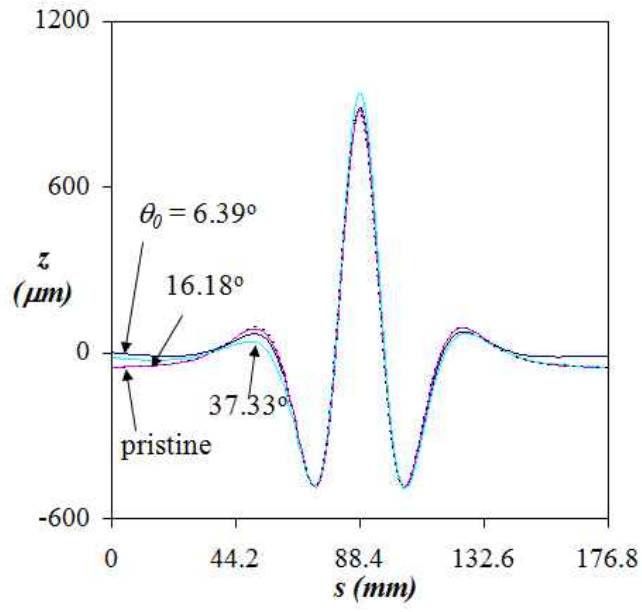

(a) along $L_{1}$-line

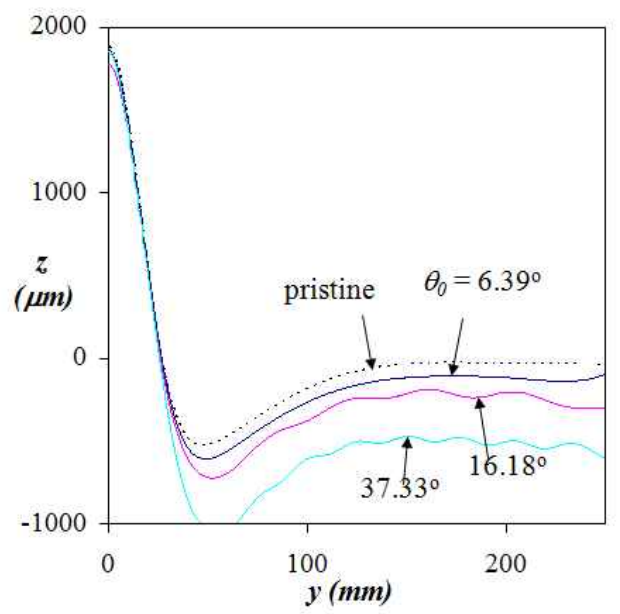

(b) along $L_{2}$-line

Fig. 8. Variation of deformed $z$-coordinates at $\mathrm{P} 2 / \mathrm{P} 1=4$

한다. 그림에서 초기 전개각이 $6.39^{\circ}$ 일 때 $d_{2}$ 곡 선은 접힌 자국이 없는 경우와 거의 동일하게 나 타났다. 그러나 초기 전개각이 클수록 $d_{2}$-값은 더 크게 나타났으며, 또한 곡선의 기울기 변화의 시 점이 늦추어져 전역주름의 발생이 지연되는 것을 확인할 수 있다.

이와는 반대로 $P_{1}$ 방향의 변위인 $d_{1}$ 은 하중비 에 따라 보다 복잡한 변화를 보였다. Fig. 9(b)에 나타난 바와 같이 $d_{1}$ 의 경우에도 $d_{2}$ 와 마찬가지 로 전역주름이 발생하는 시점에서 곡선의 기울기 가 크게 변화하였다. 그러나 $d_{l}$ 은 접힌 자국이 없거나 초기 전개각이 작을 때 하중비의 증가에 따라 약하게 감소하다가 전역주름이 발생하면서 급격히 감소한 반면 초기 전개각이 $37.33^{\circ}$ 인 경 


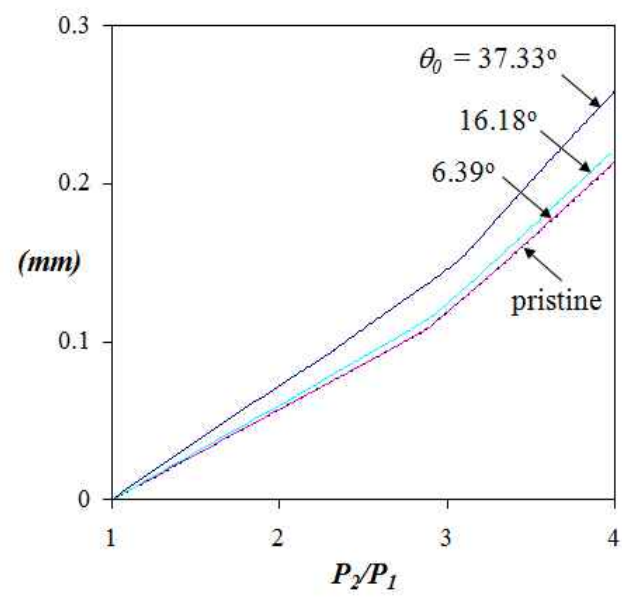

(a) $d_{2}$

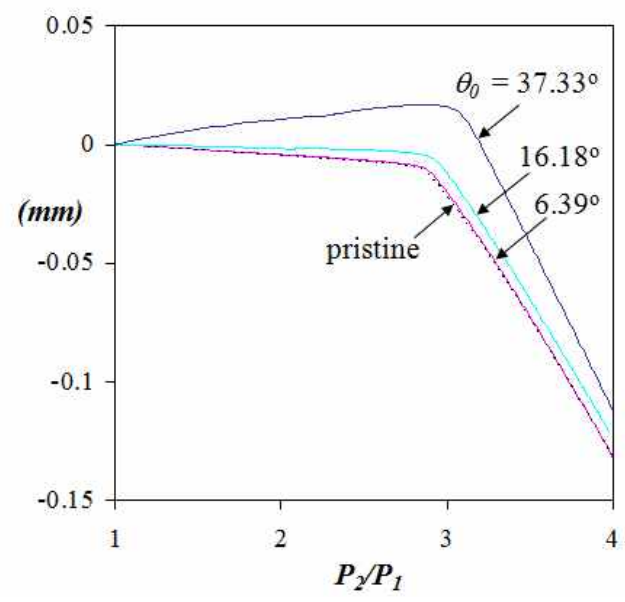

(b) $d_{1}$

Fig. 9. Variation of tip displacements versus load ratio

우에는 전역주름이 발생하기 이전에는 오히려 증 가하였다. 이는 하중비가 증가하면서 $d_{2}$ 의 증가 에 따라 포아손 수축에 의한 변형과 접힌 자국의 펴짐에 의한 변형이 동시에 발생하게 되는데, 초 기 전개각이 충분히 크면 이 펴짐에 의한 변형이 포아손 수축량보다 더 커서 $d_{1}$ 이 증가하는 것으 로 판단되었다.

\section{$\mathrm{IV}$. 결 론}

본 논문에서는 코너에서 대각선 방향으로 인 장하중을 받고 있는 멤브레인에서 접힌 자국이 주름의 발생과 성장 거동에 어떠한 영향을 미치 는지에 대해 후좌굴 해석을 통하여 연구하였다.
멤브레인은 쉘 요소로 모델링하였고 좌굴을 유발 하기 위하여 메쉬 내부에 위치하는 절점에 면외 방향으로 미소크기의 기하학적 결함을 가하였다. 다양한 초기 전개각을 가지는 멤브레인 형상을 고려하였으며 해석은 멤브레인의 기준 전개형상 단계와 주름 발생 및 성장의 두 단계로 나누어져 수행 되었다.

계산결과 접힌 자국은 국부좌굴 및 전역좌굴 의 성장 거동에 큰 영향을 미치는 것을 알 수 있 었다. 접힌 자국에 의해 유발된 비등방성은 유효 하중비를 증가시키는 효과를 주어 초기 전개각이 클수록 국부주름이 상대적으로 낮은 하중비에서 발생하였고 또한 하중비의 증가에 따라 빠른 성 장을 보였다. 접힌 자국은 전역주름의 형성에는 보다 직접적으로 영향을 미치고 있는데, 초기 전 개각이 클 경우 깊은 접힌 자국은 주름이 접힌 자국을 통과하려할 때 효과적으로 저항하여 전역 주름의 형성을 지연시키는 것으로 나타났다.

\section{후 기}

이 논문은 2007년도 충북대학교 학술연구지원 사업의 연구지원비에 의하여 연구되었음.

\section{참고문헌}

1) A. B. Chmielewski, Overview of Gossamer Structures, In Gossamer Spacecraft: Membrane and Inflatable Structures Technology for Space Application, C. H. Jenkins (ed.), AIAA, 2001.

2) C. L. Moore, Gossamer Space Structures Panel, Proceedings of 2003 IEEE Aerospace Conference, Mar 8-15, 2003, Vol. 8, pp. 3993-3994.

3) B. J. de Blonk, Membrane Mirrors in Space Telescopes, In Recent Advances in Gossamer Spacecraft, C. H. Jenkins (ed.), AIAA, 2006.

4) S. Dixit, R. Hyde, A. Weisberg, J. Early, M. Rushford and J. Britten, Development of Large Aperture, Light-Weight Fresnel Lenses for Gossamer Space Telescopes, Proceedings of 43rd AIAA/ASME/ASCE/AHS/ ASC Structures, Structural Dynamics, and Materials Conference, AIAA-2002-1203, Denver, Colorado, Apr. 22-25, 2002. 
5) G. P. Garbe, B. Wie, D. Murphy, A. Configuration on Large Deformation Analysis Ewing, L. Lichodziejewski, B. Derbes, B. for One-Dimensional Deployable Membrane, Campbell, J. Wang, B. Taleghani, S. L. Canfield, 46th SDM Conference, AIAA 2005-2046, 18-21 J. W. Beard III and J. Peddieson, Solar Sail Propulsion Technology Development, In Recent Advances in Gossamer Spacecraft, C. H. Jenkins (ed.), AIAA, 2006.

6) K. Miura, Method of Packaging and Deployment of Large Membranes in Space, International Astronautical Federation, Paper IAF-80-A31, Tokyo, Japan, 1980.

7) G. G. Horner and M. D. Elliot, A Fabrication and Development Approach for a Miura-Ori Solar Sail Model, Proc. 43rd AIAA/ASME/ASCE/AHS/ACS SDM Conference, AIAA-2002-1702, Denver, CO, April 22-25, 2002.

8) T. W. Murphey, A Nonlinear Elastic Constitutive Model for Wrinkled Thin Films, Ph.D. Dissertation, University of Colorado, 2000.

9) Y. K. Miyazaki, H. Furuya, S. Murata and K. Takadama,. Effects of Initial April 2005, Austin, TX.

10) A. Papa and S. Pellegrino, Mechanics of Systematically Creased Thin-Film Membrane Structures, Proc. 46th SDM Conference, AIAA 2005-1975, 18-21 April 2005, Austin, TX.

11) A. Gough, N. M. A. Hossain, C. H. Jenkins, J. Blandino and A. Hendricks, Experimental and Numerical Study of Creased Membranes, Proc. 46th SDM Conference, AIAA 2005-1976, 18-21 April 2005, Austin, TX.

12) N. M. A. Hossain, K. Woo and C. H. Jenkins, Nonlinear Material Response of Systematically Creased Membranes, Proc. of 47th SDM Conference, AIAA-2006-1801, 1-4 May 2006, Newport, RI.

13) www.dupont.com/kapton/

14) 우경식, 멤브레인의 접힘 거동 연구, 한국 항공우주학회지, 제 35 권 제 10 호, $2007, \mathrm{pp}$. 905-911. 